
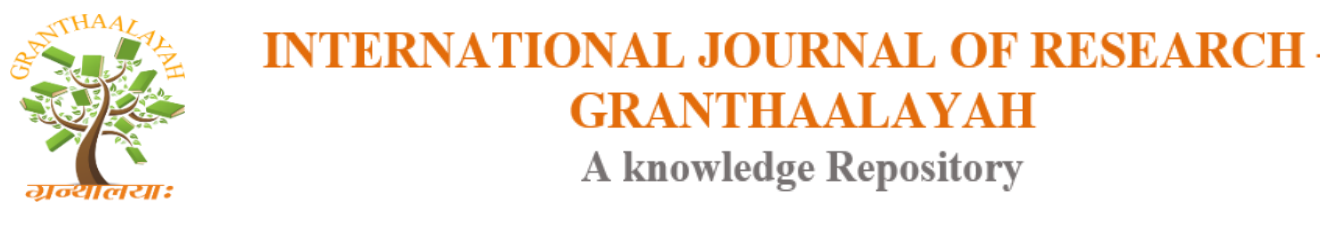

\title{
Social
}

\section{THE PLACE OF EXPEDIENT(MASLAHAT) IN THE LEADERSHIP OF THE ISLAMIC COMMUNITY}

\author{
Afsaneh Torkashvand ${ }^{1}$, Dr. Mahmood Ghayyoum Zadeh Kharanaghi ${ }^{* 2}$, Dr. Abbas Ali \\ Heidari ${ }^{3}$ \\ ${ }^{1} \mathrm{Ph}$ D Candidate, Department of Jurisprudence and Principles of Islamic Law, Khoemin Branch, \\ Islamic Azad University, Khomein, Iran \\ *2 Department of Law, Saveh Branch, Islamic Azad University, Saveh, Iran \\ ${ }^{3}$ Assistant Professor, Department of Jurisprudence and Principles of Islamic Law, Arak Branch, \\ Islamic Azad University, Arak, Iran
}

\begin{abstract}
Expediency is one of the titles which have important statuses in the Islamic jurisprudence and its association with religious decrees is clarified while determining its concept and it specifies the authorities of the prudent leader.

Expedient (Maslahat) in the view of Islam is defined as to do anything for the sake of material and spiritual benefit of the individual and society. Islamic religions do believe that Expedient (Maslahat) plays an essential role in the interpretation of the law, but there is some disagreement over its scope. Most jurisprudents consider expediency to be effective in divine rules when it is based on the expedients, and its purpose is to achieve expedients that can changed as according to the requirements of time and place. Examining and implementing this in the affairs of society is one of the duties that the Islamic ruler should observe. Therefore, it is necessary that the ruler considers the expedient in community management and use it as a key to solving problems and removing the obstacles. The present research project tries to examine the role of expedient in implementing the provincial leadership and seeks to answer the following questions:

What is the relationship between the community leadership and the welfare state?

How can the Islamic ruler utilize this rule?

Another purpose is to explain this relationship as a solution and a key to solve the problems of the society including the conflict of the rules, which mainly deals with the jurisprudential texts in a qualitative way with an analytical attitude. Various research on leadership and expediency has been done separately, but it seems that the link between these two has not been mentioned yet. So, it seems necessary to carry out a new research on this issue to answer the questions raised in relation to these two categories.
\end{abstract}

Keywords: Status; Islamic Leadership; Islamic Community; Then Rule of Expedient.

Cite This Article: Afsaneh Torkashvand, Dr. Mahmood Ghayyoum Zadeh Kharanaghi, and Dr. Abbas Ali Heidari. (2018). "THE PLACE OF EXPEDIENT(MASLAHAT) IN THE LEADERSHIP OF THE ISLAMIC COMMUNITY." International Journal of Research - Granthaalayah, 6(8), 218-225. https://doi.org/10.29121/granthaalayah.v6.i8.2018.1454. 


\section{Introduction}

Religious government clearly shows that in some cases the administration of community affairs needs some decisions and regulations which do not fall within the scope of the secondary orders. The ruler of the Islamic society has the right to establish or issue a public order for the sake of maintaining public law and order or some expedient that are different from the established divine rules. The most important issue is determining the scope of this authority. On what grounds can the ruler apply this power? Is his jurisdiction and jurisdiction limited to cases in which there is no religious law? Some believe that the jurisdiction of the ruler is limited to observing the secondary orders and only in the form of these same orders a ruler can issue provincial orders. Among them, one can mention martyr Sadr's who divides human needs into two fixed and variable categories, and believes that the orders of Islam, as a complete program for human life, should also enjoy the same variety.

On this basis, he divides Islamic rules into two categories: one of the divine rules that are forged in response to the unchangeable needs of human life, which are, as a consequence, permanent and eternal, and the rulings of the province issued to respond to the changing aspects of social life, and the ruler must take into account the public expedients based on the issuance of government decrees to regulate and regulate social affairs in this area.

Essentially, the debate of expediency has been underestimated despite its widespread use, in particular from the perspective of the source of the jurisprudence and the rulings of the government. On the other hand, expediency is much more under the influence of the Sunni viewpoint and is derived from the opinions of the jurisprudents of this religion, which needs to be considered as a broader political principle of government in a broader perspective, and one should, make a distinction between its variants, the strategic expediency (governmental) and philosophical and verbal and also jurisprudential. Although these concepts are related and may affect each other, the main purpose of the present article is the same as the strategic expedient and to solve the problems of the Islamic state in accordance with the principle of expedient.

\section{The Definition of Expedient (Maslahat)}

Maslahat is an Arabic word which is used in Islamic Jurisprudence or fiqh, Maslahat is a rule in Islamic Jurisprudence which is used in many cases. Maslahat means profit and its meaning in Islamic Jurisprudence is similar to the meaning of this word. In Islamic Jurisprudence Maslahat means doing a work in the way that cause expediency and makes profit. The council of expediency in the system of the government of Islamic republic of Iran represents a unique institute.

Literally, Maslahat means all the benefits or every step, rule and law that can protect and defend the foregoing for the sake of human beings. Some have placed the term Maslahat against corruption. (Zabidi, 1414, 4/125, Mostafavi, 1409, 6/266; Terihi, 1416, 2/38 Ghorashi, 1412, $4 / 142)$.

By reviewing various sources, different principles have been analyzed, but the essence of them is one thing: whatever is in the expedient of human beings, it is expedient and harmful to human beings. Accordingly, Ghazali says that the expedient is to achieve the purpose and the purpose of the duty is to care of the religion and the life of man and intellect and generation and property (alGhazali, 1996, 1/286). 
Some other Oslolion sholars following Ghazali believe that expedient is to win the benefits and abstain from the loss and literally means protecting the ideals and religious aims preserving the Islamic values as deemed by the ruler for all human beings and communities and they are of five things: religion, wisdom, soul, honor, and property. Anything which embraces these principles is a matter of expediency and whatever contradicts it is considered a corruption. (Feiz, 2005, 253).

\section{Expedient as A Government Decree}

One of the uses of expedient is with regard to the management of society it its general and lexical meaning of management and the issuance of government decrees. Government jurisprudence is a combination of rules and laws devised by Islamic ruler for the administration of society and is referred to as a government decree. There are several definitions for a government decree. In the definition of a government decree, one of the scholars says that government decree is issued by the ruler of the society as according to the general public (Gorji, 1369, 287.2).

Government decrees are issued within the scope of the ruler's expediency and revolve around the interests of Islam and Muslims; therefore, their issuance and enforcement are subject to expediency; regarding its content, expediency is presupposed ; in other words, the government laws and decrees in proportion to the order and subject, is dedicated to the general public and the Islamic world, and are addressed only in the field of social issues.

Praying (Ibadi) affairs while outside the realm of Islamic law and as long as they are raised in the individual sphere are not necessarily socially relevant. Allameh Tabatabai says: "Any new regulations useful in advancing the social life of the community and ending in the interest of Islam and Muslims are subject to the authority of the governor, and there is no prohibition and execution thereafter" (Tabatabaei, 2 / 43).

The distinction between these decrees and other basic rules is that government decrees do not have the status of being permanent. The decree issued by the Islamic ruler is a general decree because his rule is set by the Islamic ruler is a general first decree and at the same time a government decree.

Using the proofs of the Velayat-e Faqih, one can see that the authority that the Prophet (s) and the Imams enjoy as Muslim rulers have also been given to the general jurists with the conditions of leadership, and since the subject matter of the government decree is social expediency it is understood that the none innocent ruler should use the ideas of the experts to identify the interests of the Islamic society within the bounds of shari'a and issue a governmental decree. In other words, the Islamic ruler acts on the basis of justice and expediency of the Ummah, and in making decisions is compliant to the principle of consulting with the experts' advice and in doing so he avoids despotism.

Ayatollah Montazeri, in his book named Al-Hudod, quoted by Ibn Abi Al-Hadeed, says: "Expediency in the field of variable expediency should be placed in certain framework and principles, otherwise the owner (مبدع مصالح مرسله)says:" Imam may, for the sake of expediency kill one third of people for the sake of two thirds. (Ibn Abi al-Haidid 1741 AH, 281/1). He adds that 
the discerning of issues that are subject to temporal and spatial conditions is the responsibility of experts, and intellectuals and experts must make decisions in such cases. (Montazeri, 1400, 1/298). Therefore, the government decrees are a set of laws and regulations issued by the Islamic ruler for the proper administration of the Islamic society, the provision of social affairs, or the execution of divine orders.

Imam Khomeini as an expert on religion and one, whose entire efforts are directed towards implementing the Divine laws, forcefully defends the society's rights and demands. This reveals that laying emphasis on theo-centrism does not necessarily lead to repudiation of people and their demands or the other way round, laying emphasis on people's rights does not lead to repudiation of theo-centrism. This point was emphasized for the reason that at one time in the west's brief history, they spoke of the sovereignty of religion of the Middle Ages and public expediency was neglected; and at one time they spoke of public general expediency / interest and religion was treated unfairly. Thus, the aforesaid emphasis reveals Islam's ability to coordinate and synchronize these two fields. (Mansour-nejad, p. 6)

Imam Khomeini announced that:

"These men shall consider that expediency is one of the important affairs neglecting which sometimes causes the failure of the dear Islam. Nowadays, the Islamic world considers the Islamic republic of Iran as the display of all of the resolutions of his problems. The expediency and people are important affairs resisting which might question the Islam of the barefoot on the earth in the short and long time...".

The issuance and enforcement of government decrees is subject to expediency and has been considered when issuing a government decree. Regarding the Qur'anic principles and the validity of the government in Islam, and considering the philosophy of establishing the government and the authority of the Islamic ruler, the government decrees are considered to be religious in nature, as it is pointed in a narration by Imam Sadegh (AS). He says: since the ruling of the just ruler will restore and preserve all rights and justice and eliminates all oppression and disorder, it's obedience and strengthening the rule of justice, is in fact, to obey Allah and strengthening His religion.

Therefore, in view of the philosophy of establishing a government in Islam and the nature of the effects of government laws, it is necessary for the Islamic government and the just ruler to implement these rulings.

The necessity of expediency and government in the political thought of Imam Khomeini:

Imam Khomeini commented on the necessity of paying attention to the interests of the community by the jurists: "It is important to properly understand the government and society, according to which the Islamic system could be in the interest of the Muslims. The common Ijtihad in the religious schools is not enough, but if a person is aware of the fields of science but in general do not understand the interests of the society in the social and political contexts, and lacks the right insights and decision-making power, he is not a jurist in the fields of social and governmental issues and cannot take control of the society. (Imam Khomeini: 1999, 21/47).

To Shiite jurisprudents the issue of preserving religion and preventing the threats to Islam is of great importance. Imam Khomeini proposed to preserve religion as a base for political 
jurisprudence and the rule of Islam as a rationale and essential religious requirement. This is because of the fact that the Islamic ruler, in addition to knowing the foundations of the teachings of Islam, must also recognize the needs of society, as is fully reflected in the words of Imam Khomeini (peace be upon him). He states that the just jurisprudent possesses all the governmental authority of the Prophet (PBUH) and all the Imams to govern the community. (Imam Khomeini: 1380 , p. 55), and a lot of virtues and spirituality, does not increase the governmental authority.

The Relationship between Leadership and Expediency:

\section{Family Rights}

The government, according to the situation and time conditions, maintains the interests of society in accordance with the government decrees, and can interfere in certain matters that can be mentioned in the area of the family as follows:

\section{1) The right to divorce for women}

This was one of the issues discussed by the Guardian Council during the lifetime of the Imam, when the jurists believed that the husband would divorce the woman who was against the Shari'a, when the Imam wrote a letter to answer this question and said: "In the Name of the Most High. The method of caution is to divorce a couple with caution, otherwise she is to made to get divorced and, if not possible by the permission of the ruling ruler. (Mehrpur, 1993, 2/301).

Motahhari says: Where marriage is in such a form that it is not in the interest of the family to remain on the marriage contract, and the man is obstinate and does not divorce the woman, the religious ruler can divorce the woman. He provides an example of a government decree in divorce when he quotes that Mirzaye Shirazi in the dispute between the husband and wife and issued the decree to a woman's divorce. (Motahhari, 1360, 2/60).

2) The mother's right to custody

According to Article 1169 of the Civil Code, the right to custody and caring of the child is given to the mother during two years of childbirth, after which the father is assigned.

Imam Khomeini, in his Fatwa, believes that if a mother is divorced before her daughter reaches her 7 years of age ,her custody is not abolished as long as she is not married again and ..., if the father, after the transfer of custody to him or before his death mother is deserved to keep a child (boy or girl), albeit married to another, than the father's heir and other close relatives. (Imam Khomeini, 1425, 2/297).

With a close look at the community and considering the fact that some mothers can earn their living and are interested in keeping their children, the separation of the child can cause problems for mothers and children. It will also cause mental or physical illness, or left the children in the hands of step mothers, and deprived from affection, and according to Imam Khomeini, they become disturbed and in turn will lead to a great corruption. (Imam Khomeini, 1378, 9/136). 
Imam Khomeini, in a letter dated 26/8/90, said that if the mother's hardship is unbearable at the time of the separation from the child, the father should not separate the child from his /her mother and the custody of the mother is preserved.

\section{3) Population control}

In certain situations where the Islamic government considers the expediency of society to control population and family planning, it can only encourage society to control the population through lawful means, but not through Haram (unlawful) ways such as abortion or force people to prevent from having babies. (Lankari, 90).

\section{Leadership Authorities in the Community}

The Islamic ruler must have the authority to resolve the problems in order to manage the society. In the Islamic society, everything that is in the interest of the society and the public interest is of great priority of the Islamic ruler. And where the interests of society and people, he prefers the interest of the community to the individual. The realm of the authorities of the supreme leader is not limited and can rule by the provincial government on the basis of the ruling of the government and expediency. This is based on the Ijtihad the supreme leader holds. Of course, in the discussion of the expediency of the leader of the Islamic society, along with the consultation with experts in various fields including medical, social, cultural, etc. the final decision is made on the basis of expediency. For example, we can refer to the discussion of hoarding:

\section{1) Hoarding (Ihtekar)}

Hoarding means the gathering of essential items like wheat, barley, rice and oil etc during periods of shortages with the intention of selling them at higher rates to people who are compelled to purchase them is Harām and a Greater sin. Literally, it is taken from the root ( Hokr) which means to gather food with the intention of selling at a higher price (Ibn Manzoor, 1414, 4/220, Jowhari, $1410,2 / 635)$.

The Islamic ruler must prioritize social determinants and, in accordance with the rules of the society, to rule the social affairs, to remove the conflict and confusion in the interest of the community and the individual. Therefore, the pricing of goods and the prevention of expensiveness and, in fact, limiting the owner's freedom in price determination are also among the Islamic ruler's authorities.

The owner as according to decree 《الناسُ مسلّطون على أمو الهِهِ is free to sell his goods in an unpredictable cash deal and expensive.

This transaction is legal and lawful, and the transaction is carried out, but at the same time, the buyer has committed an illegal ( Haram ) offense; such as emergency transactions, and also in the trade of goods on credit, and under the pretext of freedom in determining the price, would raise the price which is prohibited by nature, but these deals are correct, and Islam can stop these deals through other means. Here, the Islamic government has the right to monitor prices, to prevent this freedom, and the right of the ruler himself is a good proof that they are naturally too much free and he has the right to restrict their freedom, for example, lucre and the lucre interaction is by 
nature null and void and does not make sense to say that the ruler has banned it. This is the same as a bargain deal. (Motahari, 1375, 113 and 112).

The Islamic government has the right, in a series of transactions which is authorized and permitted individually, in accordance with the law of the supreme law, to acquire and restrict ( in the circumstances which it deems) the first freedom and its source and it varies from place to place, and it should not be limited in times, the ruler must given the right to control.

Professor Mutahari says: "The religious ruler, despite the desire of the owner in the matter of hoarding, can sell the material to the market for a fair price" (Motahari, 1998, 121).

In some traditions, hoarding has been placed in four, five and six things, but considering the advancement of society and different needs of people at any time, it is possible to consider hoarding as everything that puts people's lives at distress. like money, dollar, construction materials, land, medicine and so on .

Therefore, it is determined by the need of the public what constitutes a guilty verdict. In the beginning, the person who commits hoarding is forced to sell the goods at any rate and in the absence of the provision of goods and the severity of the constraints created for the people, the Islamic ruler considers him punishable according to the interests of society.

2) The decree of the insurgent captives is the responsibility of the Islamic leader and ruler

The ruler of the Islamic government and the commander-in-chief decide on the fate of the prisoners of war and insurgents. He does what he deems fit and appropriate. In the war of Saffein, Imam Ali (AS) issued about two prisoners of war in two different ways, He released one who agreed to swear allegiance to the Imam and returned to Islam, and released him, and ordered to murder the one who who refused to swear allegiance to the Muslim Imam, (a group of scholars, $1428 \mathrm{AH}, 2 / 328$ ).

\section{Conclusion}

The ruler of the Islamic society, whoever he is, has special powers for the administration of society. He can, by introducing new regulations and issuing commands organizes the affairs of the society, or by fixing and allocating temporal holidays of religious laws, regulates social relations that, while maintaining the principles, respond to the specific needs of time and place. The provisions of such rules and regulations are called the ruling of the government and it is obligatory for the citizens to do so.

The limits of the powers of the Valie Faghih are wide and unlimited to the cases mentioned by the jurisprudents, and based on new needs and according to the bases of these powers in each period of time, and this is the factor of flexibility and in compliance with the Islamic laws and the needs of the time. Of course, at the time of the conflict, the other imperatives against Islamic rule and the rule of law are abandoned, based on the interests of Islam and Muslims. 


\section{References}

\section{The Holy Quran}

[1] Ibn-i-Manzoor, Mohammed bin Makram, Lassan al-Arab, Dar Al-Fakr, Third edition, Beirut, 1414 $\mathrm{AH}$

[2] Ibn Abi al-Haidid, Hebto Allah, Explanation of Nahj al-Balaghah, Dar al-'Al al-Islam, 1387 AH

[3] Imam Khomeini, Seyyed Rouhollah, Velayat-e Faqih, Tehran, Payam Azadi, 2001

[4] Imam Khomeini, Sahifeh Noor, Institute for Preservation and Publication of Imam Khomeini Works, Tehran, 1999

[5] Imam Khomeini, Tahrir al-Waslah, Publications Affiliated with the Community of Teachers of the Seminary of Qom, 21st Edition, $1425 \mathrm{AH}$

[6] Johari, Ismail ibn Hamad, Al-Saha'a Taj al-Lughhah and Sah'ah al-Arab, Dar al-Elm Lel Malaeen, Beirut, 1410

[7] Tabatabai, Seyyed Mohammad Hussein, Islamic Studies, Hijra, Qom, Bi Ta

[8] Tarihei, Fakhruddin, Majma Al-Bahrain, Mortazavi Bookstore, Tehran, 3rd, 1416 AH

[9] Ghazali, Mohammad, Shafa al-Ghalil, Contributed by: Hamad Kebisi, Baghdad, 1390 AH

[10] Feyz, Alireza, Principles of jurisprudence and principles, University of Tehran, Tehran, 17th, 2005

[11] Gharishi, Seyyed Ali Akbar, The Terminology of the Qur'an, Dari al-Kotobe Eslami, Tehran, 6th, $1412 \mathrm{AH}$

[12] Gorji, Abolqasem, Legal Articles, University of Tehran, Tehran, 1369

[13] Lankarani, Mohammad Fazel Movahedi, The orders of doctors and patients.

[14] Mostafavi, Hassan, The Study in the terminology of the Holy Quran, center for translation and publication of books, Tehran, 1st, $1402 \mathrm{AH}$

[15] Motahhari, Morteza, Islam and Expectations of Time, Sadra Publication, Tehran, 8th edition, 1981

[16] Motahhari, Morteza, The Issue of Rebba (lucre), Sadra Publications, Tehran, Sept. 7, 1996

[17] Motahhari, Morteza, The End of Prophecy, Sadra Publication, Tehran, 1377

[18] Montazeri, Hossein Ali, Book of Al-Hooded, Dar Al-Fakr, Qom, 1400 AD

[19] Montazeri, Hossein Ali, Islamic jurisprudential principles, Kayhan Institute, First Edition, Qom, 1409

[20] Mehrpour, Hussein, New Perspectives on Legal Issues, Tehran, Etelaat Press, 1993

[21] Vaseti Zobeidi, Seyyed Morteza Hosseini, Taj al-Urus Men Jahar Al-Qamus, Dar al-Fakr press, Beirut, first, $1414 \mathrm{AH}$

[22] Nasehi, Mostafa, Islamic Propagation Office Press, Qom, 1st, 1378

[23] Assembly of authors, Islamic jurisprudence magazine, Ahl al-Bayt (AS), Islamic Encyclopedia of Islamic Law, Qom, I, AH

[24] A group of researchers at the Research Institute for Islamic Studies, Jihad in the Mirror of the Traditions, Zamzam Hedayat, Qom, First Edition, 1428

\footnotetext{
*Corresponding author.

E-mail address: torkashvand918@ gmail.com/maarefteacher@yahoo.com/aa-heidari@ iau.arak.ac.ir
} 